\title{
JAKOB MÜLLER
}

Marjeta Humar, rojena Sluga (Kamnik, 1946), je začela delati v leksikološki sekciji Inštituta za slovenski jezik Frana Ramovša ZRC SAZU septembra 1974; leto poprej je na Filozofski fakulteti Univerze v Ljubljani diplomirala iz primerjalne književnosti in še prej iz slovenskega jezika in književnosti; pet let je poučevala slovenščino na osnovni šoli, študirala, ustvarila družino in postala mati prve hčerke in sina. $\mathrm{V}$ trigeneracijskem slovarskem kolektivu pod neformalnim vodstvom prof. Staneta Suhadolnika je kmalu spoznala temeljni koncept modernega slovaropisja: ugotavljanje prevladujoče jezikovne prakse in zvrstno-funkcijsko vrednotenje besedja. Kot soavtorica Slovarja slovenskega knjižnega jezika (SSKJ) 3-5 (1979-1991), ki je izšel v štirih ponatisih, petih elektronskih izdajah in drugi, deloma prenovljeni in dopolnjeni izdaji, je slovnično, zvrstno in pomensko analizirala in predstavljala besedje in izrazje štirih najobsežnejših, odprtih besednih vrst in sodelovala pri revizijski, končni redakciji prve izdaje.

Ob tem osrednjem in obsežnem leksikografskem delu je leta 1984 začela sodelovati tudi pri Papirniškem terminološkem slovarju (1996), s katerim je postavila vzorčni model kvalitetnih terminoloških slovarjev, ki so z njenim sodelovanjem nastali na inštitutu v naslednjih dveh desetletjih. Še pred zaključkom velikega slovarskega projekta je bila sourednica Besedišča slovenskega jezika (1987), v katerem je bilo zajetih nad 180.000 v SSKJ nesprejetih besed, v letih 1991-1992 je sodelovala v projektni skupini za enozvezkovnik, leta 1992 je začela delati tudi v terminološki sekciji inštituta, pet let pozneje pa je bila imenovana za njegovo vodjo. Sekcija je kmalu postala zelo uspešna enota inštituta in je bila dolgo edina opremljena tudi z redaktorskim računalniškim programom. $\mathrm{V}$ dveh desetletjih je kot soavtorica sodelovala pri desetih terminoloških slovarjih: že navedenem papirniškem (1996), planinskem (2002), gemološkem (2005), geografskem (2005), gledališkem (2007), farmacevtskem (2011), tolkalnem (2014), urbanističnem (2015), v letih 2009-2013 pa pri ustavljenem vojaškem; s Carlom Muccijem je izdelala izčrpen slovensko-italijanski in italijansko-slovenski slovar elektronike, elektrotehnike in telekomunikacij; leta dolgo je sodelovala pri tehniškem, umetnostnem, metalurškem, veterinarskem in drugih slovarjih; za knjižno izdajo je pripravila pravni terminološki slovar (z izrazjem do leta 1991), sodelovala pri zasnovi in gradivih za slovar pravnega izrazja Evropske 
unije in za slovar sodobnega slovenskega prava; poleg tega je spodbujala nastajanje slovarja slovenskega pravnozgodovinskega izrazja.

V letih 1996-2002 je sodelovala v evropskih terminoloških organizacijah: International Federation of Terminology Centers and Banks in v International Organization for Unification of Terminological Neologisms (oboje Varšava), še vedno pa je članica European Association for Terminology (Bruselj), kjer je bila dva mandata (2006-2010) članica upravnega odbora. Z referati je sodelovala na številnih mednarodnih terminoloških simpozijih, kongresih in konferencah: v Beogradu 1981, v Zagrebu 1989, 1997, 2001, 2005, v Varšavi 1995, 1997, 1999, 2001, 2004, v Rimu 1998, v Opatiji in Bruslju 2006, v Dublinu 2007, v Gatineauju (Kanada) 2008, v Gradcu in Budimpešti 2010, v Bukarešti 2011; v Sloveniji je nastopila na več kot tridesetih jezikoslovnih simpozijih, zborovanjih in posvetih: v Ljubljani, Pišecah, Kamniku, Mariboru, Novi Gorici, Hočah, Celju itd.

Po letu 1996 je organizirala in vodila štiri jezikoslovne simpozije: Slovensko naravoslovno-tehnično izrazje (1998), Terminologija v času globalizacije / Terminology at Time of Globalization (2004), Terminologija in sodobna terminografija (2009) in Nacionalni jeziki v visokem šolstvu / National languages in Higher Education (2010); dva zgodovinska simpozija: o Francu Mihaelu Paglovcu (1679-1759) in o Juriju Japlju (1744-1807) - vsak od navedenih je bil zaključen z obsežnim monografskim zbornikom; leta 1995 je prevzela uredništvo bienalnega Kamniškega zbornika, v letih 1992-1996 je - ob vsem drugem - tudi predavala poslovno-uradovalno slovenščino na Višji oz. Visoki upravni šoli, povrhu vsega pa je vpisala še podiplomski študij. Po intenzivnem in poldrugo desetletje trajajočem političnem angažmaju ter ob plodnem kulturnem delovanju - uredila je enajst zvezkov Kamniškega zbornika, souredila politični zbornik Demos na Kamniškem (2010), v katerem je objavila svojo politično biografijo, in zbornik pričevanj prisilno mobiliziranih v nemško vojsko (2013) ter postala spiritus agens kamniškega družbeno, kulturno in informativno nadvse delovnega Društva sv. Jakoba - je doktorski študij leta 2013 zaključila na Filozofski fakulteti Univerze v Mariboru z disertacijo Protipomenskost v slovenskem knjižnem jeziku na primeru terminoloških slovarjev, ki je leta 2016 izšla tudi kot monografija.

Kot zunanja (upokojena) sodelavka Inštituta za slovenski jezik Frana Ramovša še vedno sodeluje pri več terminoloških slovarjih.

Ob številnih in kvalitetnih leksikografskih in terminografskih delih je tudi avtorica več kot 230 jezikoslovnih razprav, člankov in zapisov, objavljenih v domačih in tujih strokovnih publikacijah.

Do srede devetdesetih let 20. stoletja prevladujejo leksikografske teme: tipologija v SSKJ nesprejetega besedja, sinonimi v zvezi z zvrstnostjo, pogostnostjo in prevzetostjo besedja, tipološka analiza uslovarjenega pesniškega besedja; lastnoimensko besedje v starejših slovenskih besedilih in slovarjih, pomembnost ponazarjalnega gradiva v splošnih in njegova nepotrebnost v terminoloških slovarjih, 
slovarsko normiranje, tj. vrednotenje besedja na podlagi prevladujoče rabe z označevalniki (kvalifikatorji) in sopomenkami ter s pobudo za sprostitev nekaterih togih in v rabi močno omajanih jezikoslovnih predpisov.

Pozneje prevladujejo terminološke in terminografske teme: vključevanje mednarodnega izrazja v slovenščino, pomenski opisi v terminografiji, tipologija žargonskega izrazja, sodobni procesi na področju slovanske terminologije in terminografije, protipomenskost $\mathrm{v}$ terminoloških slovarjih, slovaropisno izrazje, anglizmi in slovenska terminografija, stilna zaznamovanost $v$ terminografiji, analize uslovarjenega papirniškega, gorniškega, gledališkega, pravnega in farmacevtskega izrazja, pregledi zgodovinske in sodobne slovenske terminografije ...

Temeljna spoznanja njenih objav so tale. Terminografija zajema dejansko jezikovno rabo, tako pisno kot ustno. Pri uslovarjanju naj sodelujejo področni in terminografski strokovnjaki. V nasprotju s teoretičnimi postulati o ustaljenosti, neoznačenosti in nevariantnosti terminov ugotavlja sorazmerno veliko stopnjo izrazne neustaljenosti, zvrstnosti in sopomenskosti. Terminološki slovar izrazje uslovari, slovnično, zvrstno in navadno tudi pomensko opiše ter normira, tj. ovrednoti glede na pogostnost, nezaznamovanost in sistemsko ustreznost. Zaradi komunikacijskih potreb so potrebni tujejezični ustrezniki. Vsak termin je iztočnica oz. samostojna slovarska enota, v kateri so lahko dodatno navedeni pomensko sorodni izrazi in vse druge besedne zveze uslovarjene iztočnice. Terminološki slovarji vključujejo tudi žargonske izraze, ki jih besedotvorno, sobesedilno, poimenovalno, izvorno in zvrstno podrobneje analizira, vendar njihovi označevalniki v slovarjih variirajo. Terminološki slovar lahko prinaša poimenovanja za pojme, ki v nacionalnem jeziku še niso poimenovani. Glede prevzetih neizimenskih izrazov opozarja na tendenco, da se izgovorno, oblikoslovno in tudi pisno podomačujejo, kalkirajo ali ustvarjalno poimenujejo, le izjemoma ostajajo citatni, njihov zapis in ovrednotenje pa določa večinska raba. Terminografske razlage navadno niso izčrpne strokovne definicije, temveč dovolj točni enopovedni pomenski opisi, nujno sprejemljivi za strokovnjake, razumljivi pa tudi nestrokovnjakom. Ponazoritveni primeri v terminoloških slovarjih načelno niso potrebni, zelo koristne pa so slikovne ponazoritve in razne preglednice. Delanje slovarja ima tri glavne faze: načrtovalno: določitev ciljnega uporabnika, namena, obsega in tipa slovarja; pripravljalno: določitev besedilnih virov, nabor gradiva in določitev iztočnic; in obdelovalno: jezikoslovna in zvrstna obdelava iztočnic je splošna, pomenska in ustreznična pa je odvisna od izbranega tipa slovarja. Razen osrednjega, slovarskega dela obsegajo terminološki slovarji tudi seznam uporabljenih virov in upoštevane literature, pri prevodnih (ustrezničnih) slovarjih pa tudi dvojezične slovarje s tujim izrazom kot iztočnico.

Terminološki slovarji so pomembni za razvoj strok, za strokovno izobraževanje, za strokovno in poslovno komuniciranje in za nacionalno identiteto, torej imajo tudi državotvorni pomen.

$\mathrm{V}$ jezikoslovnih delih in raziskavah Marjete Humar prevladujejo slovaropisno-pragmatične teme, metode in ugotovitve, njena sistemsko čista pomenska 
delitev protipomenk na devet vrst (popolne, lastnostne, položajne, smerne, procesne, dejanjske, časne, osebne in neprave) pa je nedvomno pomemben prispevek tudi k teoretičnemu pomenoslovju, in to ne samo slovenskemu.

Tretja pomembna jezikoslovna tema Marjete Humar je javna raba slovenščine in jezikovna politika. V letih 1986-1990 je bila članica Jezikovnega razsodišča, sredi devetdesetih let 20. stoletja je bila sopodpisnica na državni zbor naslovljene zahteve, naj sprejme zakon o javni rabi slovenščine in ustanovi urad za slovenski jezik, v časopisu pa je objavila zapis Skrb za jezik kot politika. Tedaj je postala tudi članica upravnega odbora Evropske zveze za terminologijo in si ustvarila izredno širok pregled položaja nacionalnega jezika v številnih evropskih državah, v Kanadi in Južnoafriški republiki ter organizirala več simpozijev in posebno mednarodno konferenco o opuščanju nacionalnega jezika v visokem šolstvu. Po ustavi je slovenščina v Republiki Sloveniji uradni jezik, pri uradnem vrednotenju pa je diskriminirana: strokovna in znanstvena dela, objavljena $v$ katerem od svetovnih jezikov, so samo zaradi jezika točkovana veliko višje. Znanosti in stroke nedvomno morajo biti v stiku s svetom, skrb in dolžnost države pa je, da ohranja in razvija uporabo nacionalnega jezika na vseh področjih in v vseh položajih; pri tem se branilci nacionalnega jezika sklicujejo na družbeni, identitetni in nacionalni pomen popolne strokovne izobrazbe v nacionalnem jeziku, vendar ne zahtevajo, da bi se jezikovna diskriminacija pravno oziroma ustavno preizkusila.

Marjeta Humar je izjemna organizatorka, odlična voditeljica ter najboljša in daleč najuspešnejša strokovnjakinja na področju slovenske terminologije in še zlasti terminografije, ki jo je v knjižni in spletni realizaciji razvila vse do praga moderne terminološke podatkovne zbirke. 